\title{
Review
}

\section{Neurobiology of COVID-19}

\author{
Majid Fotuhi $^{\mathrm{a}, \mathrm{b}, *}$, Ali Mian ${ }^{\mathrm{c}}$, Somayeh Meysami $^{\mathrm{d}}$ and Cyrus A. Rajic,e \\ ${ }^{a}$ NeuroGrow Brain Fitness Center, McLean, VA, USA \\ ${ }^{\mathrm{b}}$ Johns Hopkins Medicine, Baltimore, MD, USA \\ ${ }^{\mathrm{c}}$ Neuroradiology Section, Mallinckrodt Institute of Radiology at Washington University in St. Louis, St. Louis, \\ MO, USA \\ ${ }^{\mathrm{d}}$ Department of Neurology, David Geffen School of Medicine at UCLA, Los Angeles, CA, USA \\ ${ }^{\mathrm{e}}$ Department of Neurology, Washington University in St. Louis, St. Louis, MO, USA
}

Accepted 29 May 2020

\begin{abstract}
Anosmia, stroke, paralysis, cranial nerve deficits, encephalopathy, delirium, meningitis, and seizures are some of the neurological complications in patients with coronavirus disease-19 (COVID-19) which is caused by acute respiratory syndrome coronavirus 2 (SARS-Cov2). There remains a challenge to determine the extent to which neurological abnormalities in COVID-19 are caused by SARS-Cov2 itself, the exaggerated cytokine response it triggers, and/or the resulting hypercoagulapathy and formation of blood clots in blood vessels throughout the body and the brain. In this article, we review the reports that address neurological manifestations in patients with COVID-19 who may present with acute neurological symptoms (e.g., stroke), even without typical respiratory symptoms such as fever, cough, or shortness of breath. Next, we discuss the different neurobiological processes and mechanisms that may underlie the link between SARS-Cov2 and COVID-19 in the brain, cranial nerves, peripheral nerves, and muscles. Finally, we propose a basic "NeuroCovid" classification scheme that integrates these concepts and highlights some of the short-term challenges for the practice of neurology today and the longterm sequalae of COVID-19 such as depression, OCD, insomnia, cognitive decline, accelerated aging, Parkinson's disease, or Alzheimer's disease in the future. In doing so, we intend to provide a basis from which to build on future hypotheses and investigations regarding SARS-Cov2 and the nervous system.
\end{abstract}

Keywords: Alzheimer's disease, anosmia, cerebrovascular disease, COVID-19, cytokines, SARS-Cov2, seizure, vasculitis

\section{INTRODUCTION}

Severe acute respiratory syndrome coronavirus 2 (SARS-Cov2) is a novel betacoronavirus that causes a variety of symptoms in patients known as coronavirus disease (COVID-19) [1]. There is a growing set of observations that suggest these symptoms include a wide range of neurological manifestations [2-5]. At the beginning of the current pandemic, the treatment of patients with COVID-19 focused on the management of fever, cough, shortness of breath, and

${ }^{*}$ Correspondence to: Majid Fotuhi, MD, PhD, Johns Hopkins Medicine, Baltimore, MD, USA. E-mail: mfotuhi@jhu.edu. respiratory failure. However, it is increasingly evident that SARS-Cov2 can contribute to a number of neurological issues including anosmia, seizures, stroke, confusion, encephalopathy, and total paralysis $[6,7]$. Up to $20 \%$ of COVID-19 patients who require intensive care unit (ICU) admission due to their neurological issues, and COVID-19 patients in ICU who have neurological deficits, are at a higher risk of mortality $[8,9]$. Patients who do leave ICU and recover from their respiratory symptoms are potentially at higher risk for long-term residual neuropsychiatric and neurocognitive conditions including depression, obsessive compulsive disorder, psychosis, Parkinson's disease, and Alzheimer's disease [10, 11]. 
In 2002, there was an epidemic of a coronavirus with severe acute respiratory syndrome (called SARS-Cov, here referred to as SARS-Cov1) which also caused a range of neurological conditions including encephalopathy, seizures, stroke, cranial nerve palsies, peripheral neuropathy, and myopathy [12]. It had a mortality rate of approximately $10 \%$ [13] that in part limited the spread of the disease [12]. In 2012, another coronavirus spread in the Middle East, called Middle East Respiratory Virus (MERS) [13]. This too resulted in clinical syndromes that involved multiple organs, including the brain, nerves, and muscles [14]. SARS-Cov2, possessing a high homology to SARS-Cov1 and MERS, appears to have the capacity to injure the central and peripheral nervous systems through direct and indirect ways $[4,11,15]$. Given that COVID-19 has created a worldwide health and economic crisis, its neurological implications have become the focus of intense clinical research.

In this review, we will summarize the published reports regarding COVID-19 patients with various neurological symptoms with a focus on our current understanding for pathophysiology of how SARSCov2 impacts the central and peripheral nervous systems. We will also address issues on how patients with Alzheimer's disease or other neurological conditions are impacted by the current pandemic. We also discuss how non-infected individuals can make themselves more resilient for the short-term and long-term impact of SARS-Cov2, in case they become infected with this virus in the future. Finally, we will highlight the importance of identifying patients who have neurological issues without typical COVID-19 symptoms, in order to reduce the risk of virus spreading in in-patient and/or out-patient neurology units.

\section{NEUROLOGICAL SYMPTOMS IN PATIENTS WITH COVID-19}

\section{Studies about anosmia or ageusia}

An MRI case study from a patient with COVID19 with acute onset of anosmia in Iran reported normal nasal mucosa (no congestion) and normal volume of olfactory bulbs bilaterally [16]. Dysfunction of smell and taste have been widely reported in patients with COVID-19 in European communities [17-19] (Table 1). Lechien and colleagues found that among 417 patients with mild to moderate COVID$19,85.6 \%$ reported having olfactory dysfunction and $88.0 \%$ had gustatory dysfunction [19]. Among 59 patients hospitalized with COVID-19 in a hospi- tal in Italy, 33.9\% reported having smell or taste impairment and $18.6 \%$ reported having both [20]. Among 202 patients with mild COVID-19 symptoms in another hospital in Italy, $64.4 \%$ had impaired sense of smell or taste [18]. However, among 214 patients hospitalized in China (Wuhan), with severe or non-severe COVID-19 symptoms, only $5.1 \%$ and $5.6 \%$ had smell or taste impairment; these impairments were more prevalent among patients with mild COVID-19 than those with severe COVID-19 (6-7\% versus $3.0 \%$ ) [6].

\section{Studies about cerebrovascular disease}

The formation of small or large blood clots, both in the brain and in multiple other organs, have been reported in a significant number of patients with COVID-19 (Table 2). In the study by Li et al., 13 of the 221 COVID-19 patients had imaging-confirmed evidence of cerebrovascular disease [21]. The majority of patients had ischemic infarcts in both small and large arterial vessels. They also noted that one patient had cerebral venous thrombosis, as confirmed by a CT venogram, and one patient had intracranial hemorrhage, confirmed by a head CT. In the study of 214 COVID-19 patients by Mao et al., five patients had ischemic strokes and one patient had intracranial hemorrhage [6]. Most of the patients with cerebrovascular disease (and other neurological deficits) in this study had severe COVID-19 symptoms. However, two of the six patients presented to hospital with signs of stroke, but did not initially have respiratory symptoms suggestive of COVID-19 [6].

Another study by Oxley et al. also highlighted that young healthy individuals can present with large strokes, with or without apparent COVID19 symptoms such as cough or fever [22]. They report a 39-year-old man with no COVID-19 symptoms who developed hemiplegia, ataxia, and reduced level of consciousness. His brain MRI showed evidence of right posterior cerebral artery occlusion. $\mathrm{He}$ underwent a cerebral angiography and clot retrieval procedures followed by antiplatelet therapy with aspirin. He was transferred to ICU and remained in critical condition. Another patient, a 37-year-old man presented with right hemiplegia and reduced level of consciousness, also without any COVID-19 symptoms. His MRI showed evidence of a left middle cerebral artery occlusion. He received a clot retrieval procedure, was then started on apixaban, improved rapidly, and was discharged to home. 
Table 1

Studies on anosmia or ageusia

\begin{tabular}{|c|c|c|c|c|}
\hline Reference & Study design & Clinical findings & Outcome measures & Comments \\
\hline Lechien et al. [17] & $\begin{array}{l}\text { Case report } \\
417 \text { mild-moderate } \\
\text { COVID-19 patients } \\
\text { from } 12 \text { European } \\
\text { hospitals } \\
\text { Mean age: } 40\end{array}$ & $\begin{array}{l}85.6 \% \text { had olfactory } \\
\text { dysfunction } \\
88 \% \text { had gustatory } \\
\text { dysfunction }\end{array}$ & $\begin{array}{l}\text { sQOD-NS } \\
\text { The smell and taste } \\
\text { component of the } \\
\text { NHANES }\end{array}$ & $\begin{array}{l}\text { More than } 95 \% \text { of the } \\
\text { patients recovered } \\
\text { their taste and smell } \\
\text { within two weeks }\end{array}$ \\
\hline Mao et al. [6] & $\begin{array}{l}\text { Retrospective case } \\
\text { series } \\
214 \text { COVID-19 } \\
\text { patients in hospitals } \\
\text { in China } \\
\text { Mean age: } 52.7\end{array}$ & $\begin{array}{l}5.1 \% \text { had a reduced } \\
\text { smell } \\
5.6 \% \text { had a reduced } \\
\text { taste }\end{array}$ & Patient Interviews & $\begin{array}{l}\text { Olfactory or gustatory } \\
\text { impairment were } \\
\text { more common in } \\
\text { patients with mild } \\
\text { COVID-19 than in } \\
\text { patient with severe } \\
\text { COVID-19 }\end{array}$ \\
\hline Spinato et al. [18] & $\begin{array}{l}\text { Case report } \\
202 \text { COVID-19 } \\
\text { patients with mild } \\
\text { symptoms in Italy } \\
\text { Median age: } 56\end{array}$ & $\begin{array}{l}64.4 \% \text { had an altered } \\
\text { sense of smell or } \\
\text { taste }\end{array}$ & $\begin{array}{l}\text { ARTIQ } \\
\text { SNOT-22 }\end{array}$ & $\begin{array}{l}11.9 \% \text { had smell and } \\
\text { taste symptoms } \\
\text { before COVID-19 } \\
\text { symptoms, } 22.8 \% \\
\text { had these symptoms } \\
\text { at the same time as } \\
\text { the COVID-19 } \\
\text { symptoms, and } \\
26.7 \% \text { had them } \\
\text { after the COVID-19 } \\
\text { symptoms began }\end{array}$ \\
\hline Giacomelli et al. [19] & $\begin{array}{l}\text { Case report } \\
59 \text { patients with } \\
\text { COVID-19 in a } \\
\text { hospital in Italy } \\
\text { Median age: } 60\end{array}$ & $\begin{array}{l}33.9 \% \text { had either } \\
\text { olfactory or taste } \\
\text { dysfunction; } 18.6 \% \\
\text { had both }\end{array}$ & $\begin{array}{l}\text { Verbal interviews and } \\
\text { surveys of hospital } \\
\text { patients }\end{array}$ & $\begin{array}{l}\text { Patients with olfactory } \\
\text { or taste dysfunction } \\
\text { were younger than } \\
\text { those patients } \\
\text { without these } \\
\text { symptoms }\end{array}$ \\
\hline Galougahi et al. [16] & Case report & $\begin{array}{l}\text { Acute onset of } \\
\text { anosmia }\end{array}$ & $\begin{array}{l}\text { MRI: Normal volume } \\
\text { of olfactory bulb }\end{array}$ & $\begin{array}{l}\text { Patient did not have } \\
\text { any nasal } \\
\text { congestion, which } \\
\text { was also evident in } \\
\text { the MRI }\end{array}$ \\
\hline
\end{tabular}

sQOD-NS, Short version of Questionnaires of Olfactory Disorders Negative Statements; NHANES, National Health and Nutrition Examination Survey; ARTIQ, Acute Respiratory Tract Infection Questionnaire; SNOT-22, Sino-nasal Outcome 22.

\section{Seizure or encephalopathy}

There are several case reports of COVID-19 patients presenting to hospitals with fever, stiff neck, confusion, changes in mental status, and/or seizures (Table 3). For example, Filtov et al. reported the case of a 74-year-old woman who presented to hospital with fever, cough, and confusion [23]. Her head CT showed evidence of an old large stroke in her left temporal lobes, but no new strokes. Moriguchi et al. reported the case of a 24-year-old man who presented to ER with headache, stiff neck, seizure, and loss of consciousness [24]. The patient's brain MRI showed hyperintense signal in the right mesial temporal lobe and hippocampus as well as the wall of the inferior horn of the right ventricle. This patient's nasal swab and cerebrospinal fluid (CSF) were positive for SARS-Cov2, as measured by PCR. He received supportive treatment in the ICU and later had significant improvements. It was noted that he had developed retrograde amnesia and did not remember events related to the onset of COVID-19 pandemic (personal communication with Dr. Moriguchi). Poyiadji et al. reported the case of a 58-year-old woman who presented to hospital in Detroit with cough, fever, and confusion. Her MRI was consistent with a diagnosis of acute necrotizing (hemorrhagic) encephalitis [25]. Duong and colleagues reported the case of a 41year-old woman with COVID-19 who presented to hospital with headache, fever, disorientation, seizure, and hallucinations [26]. Her head CT and CSF were negative. Yin et al. described yet another patient, 
Table 2

Studies on cerebrovascular disease

\begin{tabular}{|c|c|c|c|c|}
\hline Reference & Study design & Clinical findings & Test results & Comments \\
\hline Mao et al. [6] & $\begin{array}{l}\text { Retrospective case } \\
\text { series } \\
214 \text { COVID-19 } \\
\text { patients in hospitals } \\
\text { in Wuhan, China } \\
\text { Mean age: } 52.7\end{array}$ & $\begin{array}{l}5 \text { patients had } \\
\text { ischemic strokes } \\
\text { and } 1 \text { patient had an } \\
\text { intracranial } \\
\text { hemorrhage } \\
\text { Strokes were more } \\
\text { common among } \\
\text { patients with severe } \\
\text { COVID-19 }\end{array}$ & $\begin{array}{l}\text { Head CT: Stroke } \\
\text { (details of each } \\
\text { patient's imaging } \\
\text { results were not } \\
\text { reported) }\end{array}$ & $\begin{array}{l}2 \text { of the } 6 \text { patients } \\
\text { with a stroke did } \\
\text { not have typical } \\
\text { COVID-19 } \\
\text { symptoms such as } \\
\text { cough or fever } \\
\text { The } 1 \text { patient who had } \\
\text { intracranial } \\
\text { hemorrhage later } \\
\text { died }\end{array}$ \\
\hline Li et al. [21] & $\begin{array}{l}\text { Retrospective } \\
\text { observational study } \\
221 \text { consecutive } \\
\text { COVID-19 patients } \\
\text { in hospitals in } \\
\text { Wuhan, China } \\
13 \text { patients } \\
\text { Median age: } 73.5\end{array}$ & $\begin{array}{l}\text { Specific clinical } \\
\text { presentations of } \\
\text { patients were not } \\
\text { described }\end{array}$ & $\begin{array}{l}\text { Head CT: Acute } \\
\text { ischemic stroke (11 } \\
\text { patients), cerebral } \\
\text { venous thrombosis } \\
\text { (1 patient), and } \\
\text { intracranial } \\
\text { hemorrhage (1 } \\
\text { patient) } \\
\text { Cerebral Angiogram: } \\
\text { Cerebral venous } \\
\text { thrombosis } \\
\text { Patients with stroke } \\
\text { had higher levels of } \\
\text { CRP and D-D, and } \\
\text { low lymphocytes }\end{array}$ & $\begin{array}{l}\text { Among } 11 \text { patients } \\
\text { with acute stroke, } 5 \\
\text { had large vessel } \\
\text { disease, } 3 \text { had small } \\
\text { vessel stenosis, and } \\
3 \text { had cardio } \\
\text { embolic stroke } \\
53 \% \text { of patients had } \\
\text { hypertension and } \\
77 \% \text { had high blood } \\
\text { glucose levels } \\
38 \% \text { of patients with } \\
\text { stroke died in ICU }\end{array}$ \\
\hline Oxley et al. [22] & $\begin{array}{l}\text { Case report } \\
5 \text { patients under age } \\
50\end{array}$ & $\begin{array}{l}\text { Hemiplegia, facial } \\
\text { droop, dysarthria, } \\
\text { sensory deficit, } \\
\text { homonymous } \\
\text { hemianopia, } \\
\text { reduced level of } \\
\text { consciousness, gaze } \\
\text { preference, and } \\
\text { facial weakness }\end{array}$ & $\begin{array}{l}\text { MRI, Head CT, CTA, } \\
\text { CTP: Large vessel } \\
\text { occlusion in ICA, } \\
\text { MCA, or PCA }\end{array}$ & $\begin{array}{l}3 \text { of the } 5 \text { patients } \\
\text { were discharged to } \\
\text { a rehabilitation } \\
\text { facility, one to a } \\
\text { stroke unit, and one } \\
\text { to ICU } \\
\text { All patients were } \\
\text { treated with } \\
\text { antiplatelet or } \\
\text { anticoagulation; } 3 \\
\text { of the } 5 \text { patients } \\
\text { underwent clot } \\
\text { retrieval procedure }\end{array}$ \\
\hline Hou et al. [59] & $\begin{array}{l}\text { Case report } \\
75 \mathrm{~F}\end{array}$ & $\begin{array}{l}\text { Left hemiplegia } \\
\text { Right sided weakness }\end{array}$ & $\begin{array}{l}\text { Head CT: Bilateral } \\
\text { cerebral infarcts; } \\
\text { right MCA and } \\
\text { ACA, left ACA } \\
\text { Vascular Ultrasound: } \\
\text { Bilateral venous } \\
\text { thrombosis }\end{array}$ & $\begin{array}{l}\text { Patient was found to } \\
\text { have a deep vein } \\
\text { thrombosis as well } \\
\text { as a stroke }\end{array}$ \\
\hline Avula et al. [63] & $\begin{array}{l}\text { Case Report } \\
4 \text { Patients } \\
\text { Ages } 73-88\end{array}$ & $\begin{array}{l}\text { Change in mental } \\
\text { status, slurred } \\
\text { speech, hemiplegia, } \\
\text { and/or word finding } \\
\text { difficulty }\end{array}$ & $\begin{array}{l}\text { MRI, Head CT, and } \\
\text { CTA: large vessel } \\
\text { occlusion in MCA } \\
\text { or ICA in } 3 \\
\text { patients; small } \\
\text { vessel occlusion in } \\
\text { M1 segment of } \\
\text { MCA in 1 patient }\end{array}$ & $\begin{array}{l}\text { All four patients } \\
\text { presented to } \\
\text { hospital in their } \\
\text { early stages of } \\
\text { COVID-19, but had } \\
\text { extensive vascular } \\
\text { risk factors }\end{array}$ \\
\hline
\end{tabular}

CTA, computed angiography; CTP, computed tomographic perfusion; ICA, internal carotid artery; MCA, middle cerebral artery; PCA, posterior cerebral artery; ACA, anterior cerebral artery

a 64-year-old man, with COVID-19 who presented to hospital with acute onset of lethargy, irritability, dissociated speech, and confusion. His head CT and CSF were negative too [27]. Mao et al. reported that among their 214 patients hospitalized with severe COVID-19, 14.8\% had impaired consciousness and one patient experienced seizures [6]. 
Table 3

Studies on seizures and/or encephalopathy

\begin{tabular}{|c|c|c|c|c|}
\hline Reference & Study design & Clinical findings & Test results & Comments \\
\hline Helms et al. [28] & $\begin{array}{l}\text { Observational study } \\
58 \text { ICU patients with } \\
\text { COVID-19 } \\
\text { Median age: } 63\end{array}$ & $\begin{array}{l}65 \% \text { had confusion } \\
69 \% \text { had agitation }\end{array}$ & $\begin{array}{l}\text { Imaging Studies: [13 } \\
\text { patients] } 62 \% \\
\text { Meningeal } \\
\text { enhancement } \\
\text { Brain MRI Perfusion } \\
\text { Scan: [11 patients] } \\
\text { All had perfusion } \\
\text { abnormalities } \\
\text { CSF: [7 patients] All } \\
\text { negative PCR }\end{array}$ & $\begin{array}{l}15 \text { of the } 45 \text { patients } \\
\text { who were } \\
\text { discharged from the } \\
\text { ICU were found to } \\
\text { have Dysexecutive } \\
\text { Syndrome }\end{array}$ \\
\hline Duong et al. [26] & $\begin{array}{l}\text { Case report } \\
41 \mathrm{~F}\end{array}$ & $\begin{array}{l}\text { Headache, fever, } \\
\text { disorientation, } \\
\text { hallucinations, and } \\
\text { seizures } \\
\text { No respiratory } \\
\text { symptoms observed }\end{array}$ & $\begin{array}{l}\text { Head CT: Negative } \\
\text { CSF: Negative PCR }\end{array}$ & $\begin{array}{l}\text { Patient received } \\
\text { treatment for a viral } \\
\text { meningitis and } \\
\text { improved after } 9 \\
\text { days }\end{array}$ \\
\hline Lu et al. [91] & $\begin{array}{l}\text { Retrospective } \\
\text { observational study } \\
304 \text { COVID-19 } \\
\text { patients in } 14 \\
\text { hospitals in China }\end{array}$ & $\begin{array}{l}\text { No acute symptomatic } \\
\text { seizures or status } \\
\text { epilepticus were } \\
\text { observed }\end{array}$ & EEG: Not obtained & $\begin{array}{l}\text { A limitation in this } \\
\text { study was a lack of } \\
\text { EEG data }\end{array}$ \\
\hline Yin et al. [27] & $\begin{array}{l}\text { Case report } \\
64 \mathrm{M}\end{array}$ & $\begin{array}{l}\text { AMS, irritability, and } \\
\text { dissociated speech, } \\
\text { lethargy, confusion, } \\
\text { and neck stiffness }\end{array}$ & $\begin{array}{l}\text { Head CT: Negative } \\
\text { CSF: Negative PCR }\end{array}$ & $\begin{array}{l}\text { Patient was treated } \\
\text { with antiviral } \\
\text { medications and } \\
\text { traditional Chinese } \\
\text { Medicine } \\
\text { Patient was } \\
\text { discharged to a } \\
\text { quarantine facility } \\
\text { after a few weeks }\end{array}$ \\
\hline Mao et al. [6] & $\begin{array}{l}\text { Retrospective case } \\
\text { series } \\
214 \text { COVID-19 } \\
\text { patients in hospitals } \\
\text { in Wuhan, China } \\
\text { Mean age: } 52.7\end{array}$ & $\begin{array}{l}\text { Among } 88 \text { patients } \\
\text { with severe } \\
\text { COVID-19, } 14.8 \% \\
\text { had impaired } \\
\text { consciousness } \\
1 \text { patient had a tonic } \\
\text { clonic seizure }\end{array}$ & $\begin{array}{l}\text { No specific data for } \\
\text { head CT, CSF, or } \\
\text { EEG }\end{array}$ & $\begin{array}{l}\text { Changes in mentation } \\
\text { were in part } \\
\text { attributed to } \\
\text { medications, } \\
\text { multi-organ failure, } \\
\text { and being in ICU }\end{array}$ \\
\hline Filatov et al. [23] & $\begin{array}{l}\text { Case report } \\
74 \mathrm{M} \text { with COVID-19 }\end{array}$ & $\begin{array}{l}\text { Fever, cough, and } \\
\text { encephalopathy } \\
\text { History of atrial } \\
\text { fibrillation, stroke, } \\
\text { PD, COPD, and } \\
\text { recent cellulitis }\end{array}$ & $\begin{array}{l}\text { Head CT: Negative } \\
\text { except for a large, } \\
\text { old stroke } \\
\text { EEG: Diffused } \\
\text { slowing in the left } \\
\text { temporal lobe }\end{array}$ & $\begin{array}{l}\text { Patient was admitted } \\
\text { to the ICU and } \\
\text { received } \\
\text { hydroxychloroquine }\end{array}$ \\
\hline Ye et al. [74] & $\begin{array}{l}\text { Case report } \\
\text { Adult } \mathrm{M}\end{array}$ & $\begin{array}{l}\text { Fever, shortness of } \\
\text { breath, and } \\
\text { confusion }\end{array}$ & CSF: Negative & $\begin{array}{l}\text { Patient received } \\
\text { supportive } \\
\text { treatment including } \\
\text { mannitol infusion } \\
\text { and was then } \\
\text { discharged to home }\end{array}$ \\
\hline Moriguchi et al. [24] & $\begin{array}{l}\text { Case report } \\
24 \mathrm{M} \text { with COVID-19 }\end{array}$ & $\begin{array}{l}\text { Headache, stiff neck, } \\
\text { seizure, and LOC }\end{array}$ & $\begin{array}{l}\text { Brain MRI: } \\
\text { Hyperintensities in } \\
\text { right temporal lobe } \\
\text { and hippocampus } \\
\text { CSF: Positive PCR for } \\
\text { SARS-Cov2 }\end{array}$ & $\begin{array}{l}\text { Patient recovered and } \\
\text { had residual } \\
\text { retrograde amnesia } \\
\text { for } 2 \text { years } \\
\text { Patient did not } \\
\text { remember events } \\
\text { related to } \\
\text { COVID-119 } \\
\text { pandemic }\end{array}$ \\
\hline
\end{tabular}


Table 3

(Continued)

\begin{tabular}{|c|c|c|c|c|}
\hline Reference & Study design & Clinical findings & Test results & Comments \\
\hline Poyiadji et al. [25] & $\begin{array}{l}\text { Case report } \\
58 \mathrm{~F}\end{array}$ & $\begin{array}{l}\text { Confusion, } \\
\text { disorientation }\end{array}$ & $\begin{array}{l}\text { Head CT: } \\
\text { Hypoattenuation in } \\
\text { the thalami } \\
\text { MRI: Hemorrhagic } \\
\text { rim enhancement in } \\
\text { the thalami, } \\
\text { temporal lobe, and } \\
\text { sub-insular region } \\
\text { CTA \& CTV: Normal }\end{array}$ & $\begin{array}{l}\text { Patient was treated } \\
\text { with IVIg and } \\
\text { recovered }\end{array}$ \\
\hline
\end{tabular}

AMS, altered mental status; LOC, loss of consciousness; PD, Parkinson's disease; COPD, chronic obstructive pulmonary disease; CSF, cerebrospinal fluid; PCR, polymerase chain reaction (for SARS-Cov2).

In a study of ICU patients with severe COVID-19 and Acute Respiratory Distress Syndrome (ARDS) $(N=58), 65 \%$ had confusion and $69 \%$ had agitation [28]. Among the 13 patients in this study who underwent MRI because of unexplained encephalopathic features, $62 \%(8 / 13)$ had leptomeningeal enhancement, 23\% (3/13) had ischemic stroke, and all 11 patients who underwent perfusion imaging had bilateral frontotemporal hypoperfusion. Interestingly, two of their patients who had diffusion weighted MRIs were found to have experienced acute small strokes which were not expected based on their neurological exams. One patient had an asymptomatic acute ischemic stroke in his cerebellum [28].

\section{Studies about peripheral nervous system}

SARS-Cov2, similar to SARS-Cov1, can cause serious injury to cranial nerves, peripheral nerves, and muscles (Table 4). Facial weakness, difficulty breathing, being unable to stand or walk, or having difficulty weaning off respiratory ventilators may be in part due to Guillain-Barre syndrome (GBS) brought on by COVID-19. Gutierrez-Ortiz et al. report treating two patients who presented with eye movement abnormalities consistent with a diagnosis of Miller-Fisher Syndrome and polyneuritis cranialis. Their symptoms included anosmia, ageusia, areflexia, ataxia, internuclear ophthalmoplegia, and fascicular oculomotor palsy [29]. The blood tests for one of these patients was positive for GD1b. These patients promptly received IVIg and had a rapid recovery. Another patient with COVID-19, reported by Toscano et al., presented with severe facial weakness as well as sensory ataxia [30]. His brain MRI showed evidence of enhancement in the facial nerve. He too responded well to treatment with IVIg and improved within a week [30]. The four other patients in this report all had more typical GBS and variable degrees of typical COVID-19 symptoms. Overall, it appears that COVID-19 patients who presented with various degrees of cranial nerve and limb weakness and who were promptly diagnosed with GBS had a favorable prognosis.

In the observational study by Mao et al., COVID19 patients in the ICU had multiple etiologies for lethargy, muscle atrophy, and weakness [6]. However, their muscular symptoms were above and beyond what would be expected in a critical care setting. They reported that $19.3 \%$ of their patients with severe COVID-19 had evidence of marked muscle injury [6]. Similar findings have been reported for COVID-19 patients in other ICU settings [31].

\section{PATHOPHYSIOLOGY OF NEUROLOGICAL ABNORMALITIES IN COVID-19}

The binding of SARS-Cov2 to angiotensin converting enzyme 2 (ACE2) is a critical step in the pathophysiology of clinical manifestations in patients with COVID-19 [32] (Fig. 1). The function of ACE2 in normal human physiology is to regulate blood pressure via inhibition of the angiotensinrenin-aldosterone pathways [33]. ACE2 facilitates conversion of angiotensin II to angiotensin(1-7) [33]. Higher levels of angiotensin II are associated with vasoconstriction, kidney failure, heart disease, apoptosis, and oxidative processes that accelerate aging and promote brain degeneration [33]. Several cardiovascular medications including statins and angiotensin receptor blockers exert their effects in part through ACE2 [34]. This enzyme protein in the cell membranes of multiple organs also happens to serve as the receptor for SARS-Cov2 [32]. ACE2 deficiency lessens the impact of SARS-Cov2 infection [32]. As such, ACE2 can actually serve as 
Table 4

Studies on peripheral nervous system

\begin{tabular}{|c|c|c|c|c|}
\hline Reference & Study design & Clinical findings & Test results & Comments \\
\hline Gutierrez-Ortiz et al. [29] & $\begin{array}{l}\text { Case report } \\
50 \mathrm{M} \text { and } 39 \mathrm{M} \\
\text { COVID-19 patients } \\
\text { with cranial nerve } \\
\text { deficits }\end{array}$ & $\begin{array}{l}\text { Headache, anosmia, } \\
\text { ageusia, III nerve } \\
\text { palsy, bilateral VI } \\
\text { nerve palsy, ataxia, } \\
\text { and areflexia }\end{array}$ & $\begin{array}{l}\text { Positive GD1b in one } \\
\text { patient's blood } \\
\text { CSF: Negative PCR in } \\
\text { both patients }\end{array}$ & $\begin{array}{l}\text { Neither one of the } \\
\text { patients had } \\
\text { shortness of breath } \\
\text { Both improved with } \\
\text { an IVIg } \\
\text { Both were discharged } \\
\text { to home }\end{array}$ \\
\hline Mao et al. [6] & $\begin{array}{l}\text { Retrospective case } \\
\text { series } \\
214 \text { hospitalized } \\
\text { COVID-19 patients } \\
\text { in Wuhan, China } \\
\text { Mean age: } 52.7\end{array}$ & $\begin{array}{l}8.9 \% \text { had Peripheral } \\
\text { nerve disease } \\
7 \% \text { had muscular } \\
\text { injuries } \\
\text { Among patients with } \\
\text { severe COVID-19, } \\
19.3 \% \text { had evidence } \\
\text { of muscle injury }\end{array}$ & $\begin{array}{l}\text { Elevated levels of } \\
\text { creatine kinase and } \\
\text { lactate } \\
\text { dehydrogenase }\end{array}$ & \\
\hline Toscano et al. [30] & $\begin{array}{l}\text { Case report } \\
5 \text { hospitalized } \\
\text { COVID-19 patients }\end{array}$ & $\begin{array}{l}\text { Flaccid diplegia or } \\
\text { tetraplegia, bulbar } \\
\text { signs, tongue } \\
\text { weakness, and } \\
\text { sensory ataxia }\end{array}$ & $\begin{array}{l}\text { Spine MRI: [1 patient] } \\
\text { Enhancement of the } \\
\text { caudal nerve root } \\
\text { Brain MRI: [1 patient] } \\
\text { Enhancement of the } \\
\text { facial nerve } \\
\text { (bilaterally) } \\
\text { EMG/NCS: [2 } \\
\text { patients] Sensory } \\
\text { motor axonal } \\
\text { neuropathy and } \\
\text { demyelinating } \\
\text { neuropathy } \\
\text { CSF: [4 patients] } \\
\text { Negative for } \\
\text { SARS-Cov2 by } \\
\text { PCR }\end{array}$ & $\begin{array}{l}\text { Average time from } \\
\text { presenting } \\
\text { COVID-19 } \\
\text { symptoms to GBS } \\
\text { was 5-10 days } \\
\text { All patients were } \\
\text { treated with IVIg } \\
\text { After } 4 \text { weeks, } 2 \text { of } \\
\text { the } 5 \text { patients } \\
\text { remained in the } \\
\text { ICU, } 2 \text { underwent } \\
\text { physical therapy } \\
\text { due to flaccid } \\
\text { paraplegia and } \\
\text { limited upper limb } \\
\text { movement, and } 1 \\
\text { was discharged and } \\
\text { had normal motor } \\
\text { function }\end{array}$ \\
\hline Zhao et al. [62] & $\begin{array}{l}\text { Case report } \\
61 \text { F with COVID-19 }\end{array}$ & $\begin{array}{l}\text { Acute weakness in } \\
\text { both legs, and } \\
\text { severe fatigue }\end{array}$ & $\begin{array}{l}\text { Low lymphocytes and } \\
\text { thrombocytopenia } \\
\text { EMG: Delayed } \\
\text { latencies and absent } \\
\text { F waves }\end{array}$ & $\begin{array}{l}\text { Patient did not have } \\
\text { fever, cough, chest } \\
\text { pain, or diarrhea at } \\
\text { the time of } \\
\text { admission } \\
\text { On day } 8 \text { of } \\
\text { hospitalization she } \\
\text { had a dry cough, } \\
\text { fever, and tested } \\
\text { positive for } \\
\text { SARS-Cov2 }\end{array}$ \\
\hline Sedaghat et al. [77] & $\begin{array}{l}\text { Case report } \\
65 \mathrm{M} \text { with COVID-19 }\end{array}$ & $\begin{array}{l}\text { Fever and cough for } \\
\text { two weeks, then } \\
\text { developed } \\
\text { quadriplegia and } \\
\text { facial paresis }\end{array}$ & $\begin{array}{l}\text { Brain MRI: Negative } \\
\text { C-Spine MRI: } \\
\text { Negative } \\
\text { EMG/NCS Study: } \\
\text { Acute Motor } \\
\text { Axonal Neuropathy }\end{array}$ & $\begin{array}{l}\text { Patient received an } \\
\text { IVIg and improved }\end{array}$ \\
\hline
\end{tabular}

IVIg, intravenous immunoglobulin; EMG/NCS Study, Electromyogram and Nerve Conduction Studies.

a target for therapeutic agents against SARS-Cov2 [35].

ACE2 has a wide distribution in multiple organs including the nose, lungs, kidneys, liver, blood vessels, immune system, and the brain [36, 37]. After binding ACE2 in respiratory epithelial cells and then epithelial cells in blood vessels, SARS-Cov2 triggers the formation of a cytokine storm, with marked elevation in levels of interleukin-1, interleukin-6, and tumor necrosis factor $[38,39]$. High levels of these cytokines increase vascular permeability, edema, and widespread inflammation with consequent damage in 


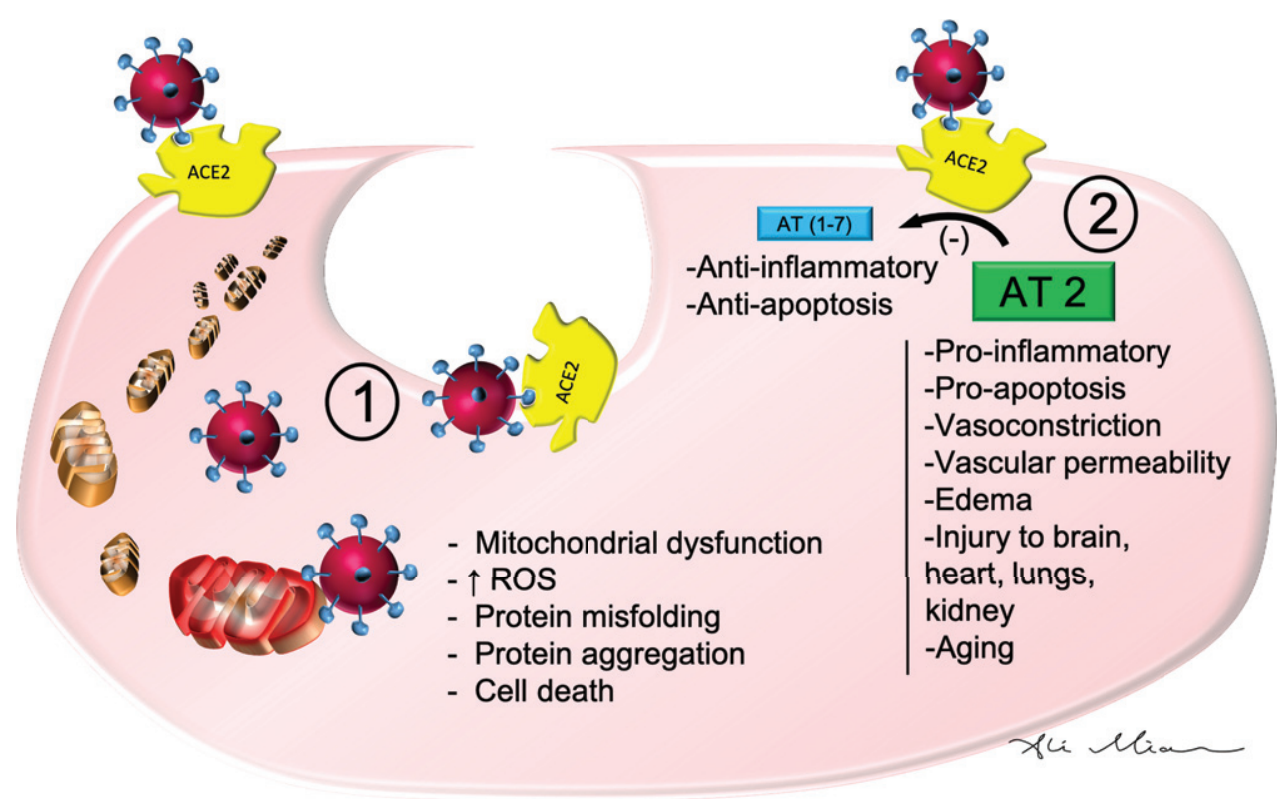

Fig. 1. SARS-Cov2: Cellular mechanism of action. SARS-Cov2 binds ACE2 to enter epithelial cells of blood vessels and cells in multiple other organs. 1) Once internalized, it can cause damage to mitochondria and lysosomes which in turn may result in increased reactive oxygen species (ROS), protein misfolding, protein aggregation, and cell death. 2) By binding to ACE2, SARS-Cov2 also downregulates and inhibits the metabolic conversion of Angiotensin 2 (AT2) to AT(1-7). The resulting higher levels of AT2 is associated with pro-inflammatory markers, vasoconstriction, vascular permeability and edema, vascular injury to cells in the lungs, brain, heart, and kidneys as well as processes involved in pro-apoptosis and aging.

multiple organs [40]. The cytokine storm also triggers hypercoagulation cascades to cause small and large blood clots [39]. Combined hyperactivation of inflammatory markers, vascular injury, and coagulation factors contributes to ARDS, kidney failure, liver injury, heart failure, myocardial infarction, as well as multiple neurological conditions, which will be discussed below. A direct entry of SARS-Cov2 into the brain has been described for other coronaviruses and may play a role in SARS-Cov2's possible contribution to demyelination or neurodegeneration [2, 12].

Patients who suffer from COVID-19 complications, including hospitalization and being isolated from their family members, experience a great deal of psychological stress [41]. Being isolated is similar to the stress of physical immobilization, which is associated with a sharp increase in cortisol and steroid levels [41]. Extreme stress levels also heighten the level of cytokines and contribute to medical complications in COVID-19 patients who are already experiencing organ damage due to a cytokine storm [42]. Sustained exposure to stress and high level of cytokines in these patients may contribute to a variety of neuropsychiatric and neurocognitive symptoms in the long term [43] (discussed below).

\section{Anosmia and ageusia}

Some of the anosmia in patients with COVID-19 can potentially be due to nonspecific upper respiratory infection symptoms. However, the recent literature suggests that the traditional nasal symptoms seen in influenza or rhinovirus are often absent in patients with COVID-19 [44]. In fact, patients who have COVID-19 do not develop significant nasal congestion or rhinorrhea [44, 45]. Moreover, patients with anosmia sometimes report having the false perception of altered or loss of taste [46]. The close relationship between olfactory and gustatory functions may account for the reason they misinterpret having loss of taste despite having experienced only loss of smell, as it can happen with some upper respiratory infection [46]. However, several studies have demonstrated that taste dysfunction in patients with COVID-19 appears to be more common than olfactory dysfunction and that 10.2-22.5\% of COVID-19 patients have taste dysfunction without olfactory dysfunction [17, 19, 45, 47, 48]. Thus, ageusia is a specific symptom in patients with COVID-19 that is different from flu-like upper respiratory congestion or misinterpretation of taste perception due to loss of olfactory function [47]. 


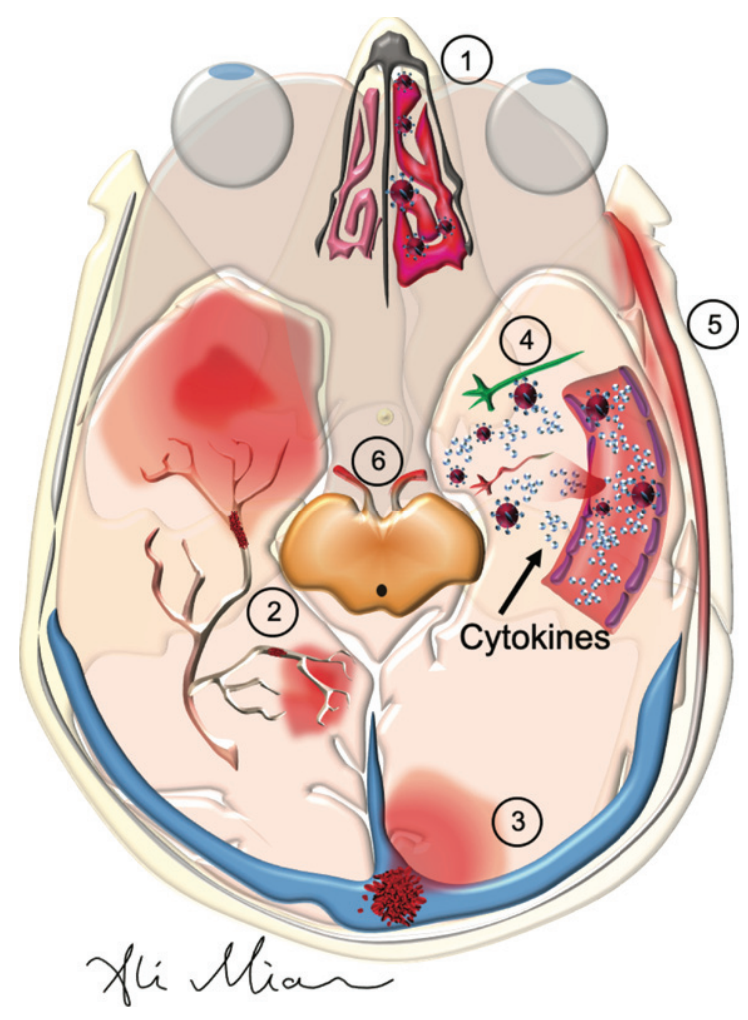

Fig. 2. SARS-Cov2: Pathophysiology of action in the nose, cranial nerves and the brain. SARS-Cov2 can cause a variety of neurological symptoms in patients with COVID-19 such as anosmia, strokes, encephalopathy, meningitis, and cranial nerve injury. 1) By binding and inhibiting nasal (and gustatory - not shown) epithelial cells, it reduces the sense of smell and taste. 2) By activating the cytokines and hypercoagulation pathways in the blood, it results in the formation of small and large vessel occlusion in cerebral arteries. 3) Formation of blood clots in the cerebral veins can results in cerebral venous thrombosis. 4) High levels of cytokines in the cerebral vessels can damage the blood-brain barrier, and once infiltrate the brain, damage neurons and glia which results in seizures and/or encephalopathy. 5) Damage to arteries in meninges can result in meningitis. 6) Formation of auto-antibodies, known as molecular mimicry, may lead to damage to cranial nerves (see Fig. 3).

Impairment in olfactory and gustatory functions in patients with COVID-19 are likely due to the SARSCov2 infection of the epithelial cells of nasal and oral mucosa [17, 47] (Fig. 2). High densities of ACE2 are present in olfactory epithelial cells, nasopharynx, and oral mucosa $[49,50]$. By binding to the ACE2 in nasal and oral mucosa, SARS-Cov2 can inhibit the function of sensory receptor cells that mediate olfaction and gustation.

A retrograde transport from nasal mucosa to the brain has been described for SARS-Cov1 [51, 52]. As such, it is conceivable that SARS-Cov2 can also cross the cribriform plate and bind to neurons in the olfactory bulb, thereby reducing the perception of olfac- tion through a central mechanism [53]. Similarly, a retrograde transport of this virus from the gustatory receptor cells in the tongue to damage the neurons in the nucleus solitarius in medulla can potentially account for ageusia sensation in patients with COVID-19 [54]. A postmortem immunohistochemical study detected the presence of the SARS-Cov1 by electron microscopy in some neurons, but not in those in the olfactory bulb [55]. In one case report of anosmia in a patient with COVID-19, the brain MRI showed normal volume in olfactory bulb [16]. Further neuropathological and imaging studies with a with special focus on brain stem and olfactory bulb can help to determine if SARS-Cov2 is in fact capable of reaching the brain structure related to olfaction and gustatory function [52]. For now, given that smell and taste dysfunction are common among patients with COVID-19 and do often improve within weeks, the possibility for a central etiology remains unlikely.

The marked difference in the reported percentage of COVID-19 patients who suffer from anosmia or ageusia from Asia and Europe needs further evaluation $[6,17]$. The one study from hospitalized patients with COVID-19 in China (Wuhan) found that only $5 \%$ of patients suffered from smell and taste impairments [6]. This is in contrast to the frequency of $33.9 \%$ to $88.0 \%$ for reported olfactory and/or gustatory dysfunction in three European studies of COVID-19 patients [9, 17, 18]. A marked variation between populations of patients with COVID-19 between Asia and Europe with regards to smell and taste, once confirmed with further studies and results from objective measures, can be explained by ACE2 polymorphism. Preliminary studies suggest that East Asian populations may have different allele frequencies of ACE2 [56] and that some ACE2 variants may have reduced capacity to bind SARS-Cov1 [57]. As such, symptoms and outcomes of patients with COVID-19 may vary greatly depending on which variant to ACE2 they have in different tissues. This possibility has strong clinical implications and needs to be further investigated.

\section{Cerebrovascular disease}

COVID-19 patients who experience cerebrovascular disease often have hypertension [58]. Strokes, as well as other neurological deficits, are also more common in patients with COVID-19 who suffer from diabetes [12, 21, 58, 59]. Increasing evidence shows that higher body mass index is associated with more severe COVID-19, that mortality of COVID-19 is 
higher in obese patients, and that obesity by itself can be considered a risk factor for developing COVID19 [60, 61]. As such, hypertension, pre-diabetes, and obesity are major risk factors for cardiovascular and cerebrovascular events in patients with COVID-19 [62]. Given these findings, we need to remind patients with these vascular conditions to be extra cautious not to get infected by SARS-Cov2.

There is now compelling evidence that COVID19 patients are at increased risk for excessive level of hypercoagulopathy [40]. Cerebral angiography and venography findings suggest that blood clots for ischemic stroke in COVID-19 patients can happen in both cerebral arteries and cerebral veins [21, 63] (Fig. 2). Blood clots in these patients also lead to myocardial infarctions, pulmonary embolisms, and renal failure [40, 64]. Sometimes an ischemic stroke can happen to a patient at the same time as a deep venous thrombosis [59]. The hypercoagulable state in these patients has in turn been attributed to higher levels of inflammatory markers such as C-Reactive Protein, ferritin, interleukin-1, interleukin-6, TNFalpha, and d-dimer [65]. More research is needed to determine how exactly binding of SARS-Cov2 to ACE2 triggers the cytokine storm and the secondary hypercoagulation - factors that contribute to a major morbidity and mortality in COVID-19 patients.

Though most of the reported strokes in patients with COVID-19 have been due to ischemic events, a handful of cases with intracranial hemorrhage have been reported as well $[12,21,66]$. The exact mechanism for how SARS-Cov2 causes intracranial hemorrhage remains poorly understood. One possibility is that by binding and downregulating ACE2, SARS-Cov2 slows the conversion of angiotensin II to angiotensin(I-7) [33]. Higher levels of angiotensin II are associated with vasoconstriction and peripheral vascular resistance (Fig. 1). The vasoconstriction associated with suppressing ACE2 can contribute to rupture of blood vessels in the brain. Another possibility relates to possible polymorphism of ACE and increased risk of intracranial hemorrhage, especially in Asian population [67].

\section{Seizures and encephalopathy}

Patients in ICU settings with multiple medical conditions, and on a long list of medications, can develop memory loss, slow processing speed, delirium, or even coma [68]. As such, a decline in mentation among patients with severe COVID-19 may not necessarily represent a direct brain injury brought on by the SARS-Cov2. However, it appears that these patients experience encephalopathy and delirium at a greater rate than would be otherwise expected in ICU settings [6, 69].

Analysis of the limited COVID-19 literature favors that SARS-Cov2 triggers an immune-mediated encephalopathy more than a direct viral encephalopathy [12]. SARS-Cov2 activation of cytokines such as interleukin-1, interleukin-16, and TNF-alpha causes injury to the blood-brain barrier (BBB) [12]. With increasing damage to $\mathrm{BBB}$, cytokines penetrate the brain parenchyma, especially in temporal lobes where BBB is weaker [70,71]. Strong inflammatory response and entry of blood material into the brain results in seizures and encephalopathy [12]. A direct viral infection of neurons to cause seizures is plausible as well. With the permeation of blood content into the brain, viral particles can enter and damage neurons directly (Fig. 2). Neurons do have ACE2, and postmortem pathological studies have detected SARS-Cov1 (by electron microscopy) in some neurons of patients with SARS-ARDS [72]. However, with the exception of two case reports with positive PCR in CSF for SARS-Cov2 in two patients with meningitis/encephalitis[24, 73], all other studies in which CSF was tested failed to find SARS-Cov2 by PCR [23, 27, 28, 74] (Table 3). This failure to find traces of SARS-Cov2 in most reported studies of patients with COVID-19 encephalopathy could be due to a lack of optimal testing techniques in CSF for this virus, or more likely, a lessor role of large viral load in CSF/brain [75].

Patients with COVID-19 who present with acute headache, nuchal rigidity, seizure, and confusion may be experiencing meningitis [24]. The meninges are rich in blood vessels and have and also contain high levels of ACE2 [37]. Damage to these blood vessels and the inflammation in the meninges can in turn result in symptoms of meningitis [12].

\section{Cranial nerves, peripheral nerves, and muscle}

Guillain-Barre syndrome (GBS), associated with ascending paralysis and some degree of sensory loss or cranial nerve injury, commonly occurs after certain bacterial or viral infections. GBS has been reported in patients who developed the SARS-Cov1 infection in 2002-2003 [12]. Now, several reports have outlined typical GBS axonal neuropathy, demyelination, or cranial nerve palsy in patients with COVID-19 [6, $29,30,76,77]$ (Table 4). GBS is believed to occur as a result of "molecular mimicry," which refers to cross- 


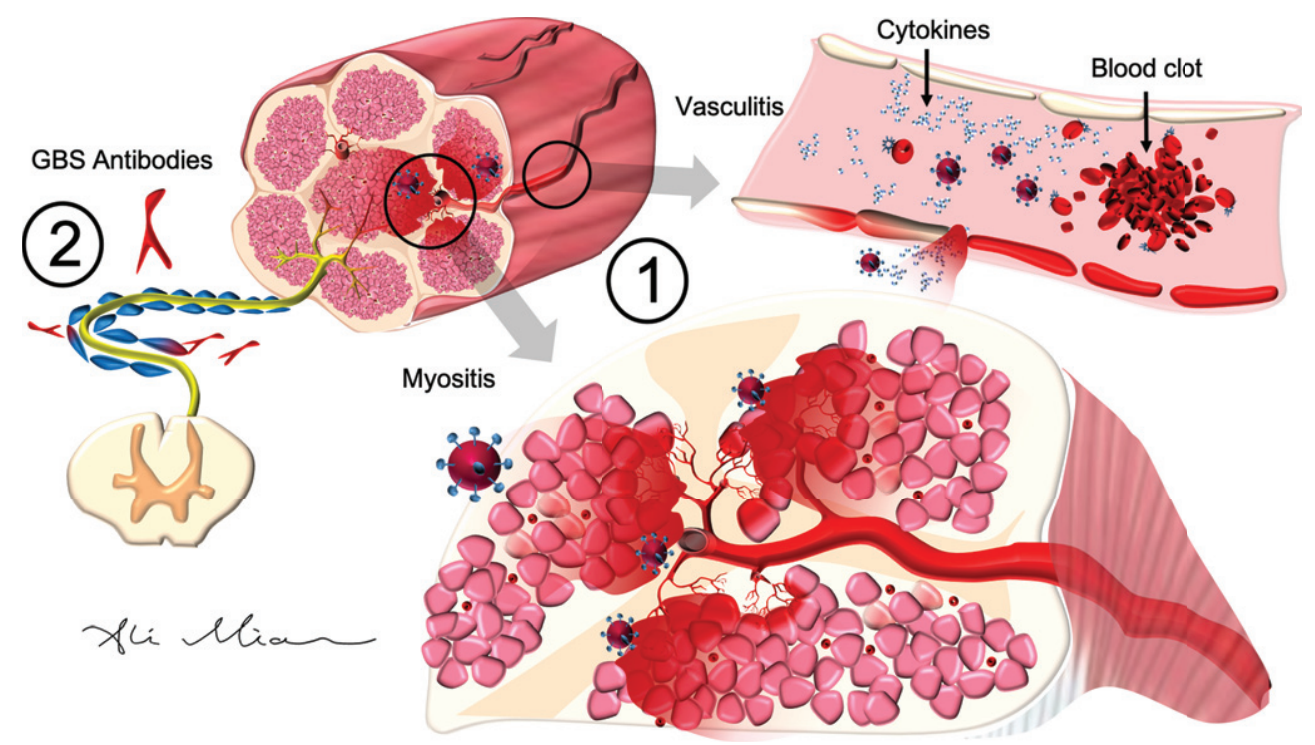

Fig. 3. SARS-Cov2: Pathophysiology of action in peripheral nerves and muscle. 1) SARS-Cov2 activation of cytokines causes inflammatory injury to epithelial cells in the blood vessels (vasculitis) and muscles cells (myositis). In cardiac arteries and muscles (not shown), cytokine storm, triggered by SARS-Cov2, can result in hypercoagulopathy and formation of blood clots (myocardial infarction) or endocarditis. 2) SARS-Cov2 can trigger the formation of autoantibodies (such as GD1a) which react with antigens on axons and myelin cells to cause Guillain-Barre syndrome (GBS).

reactivity of natural immunoglobulins-formed in response to a bacterial or viral antigen — with specific proteins on the myelin, axon, or neuro-muscular junction [78]. The cytokines activated by SARS-Cov2 can also trigger vasculitis in and around nerves and muscles, with or without a molecular mimicry (Fig. 3) [78]. A direct invasion by the virus to the peripheral nerves can potentially occur, but the lack of any SARS-Cov2 finding in the CSF to date makes this unlikely $[29,30]$. For now, the pattern of clinical presentations and rapid response to IVIg favors an immune-mediated etiology for peripheral and cranial neuropathy in patients with COVID-19.

Muscle injury and high levels of creatine kinase in COVID-19 patients in ICU can be attributed to critical care neuropathy and/or myopathy [79]. Sedating and paralyzing medications given to patients for ICU protocols can also make these patients weak and unable to stand or walk. However, the time course of severe muscle weakness in COVID-19 patients suggests that a vasculitis or myositis etiologies may be involved (Fig. 3) [79]. With regards to cardiac muscle, there is evidence that both myocarditis due to SARSCov2 as well as myocardial infarction due to cytokine storm, hypercoagulability, and ischemia can happen at the same time [64]. A neuroinvasion of brain stem neurons by SARS-Cov 2 causing muscle weakness in ICU patients with ARDS is also under a great deal of investigation [52, 80-82].

\section{NEUROCOVID STAGING, FROM ANOSMIA TO ENCEPHALOPATHY}

Based on the analysis of the potential pathophysiological mechanisms involved in neurological manifestations of SARS-Cov2, we propose a conceptual framework of "NeuroCovid Staging" that can serve as a basis for future discussions and investigations.

- NeuroCovid Stage I: The extent of SARS-Cov2 binding to ACE2 receptors is limited to the nasal and gustatory epithelial cells. The cytokine storm activated by the virus remains low and controlled. Patients may have only smell or taste impairments and often recover without any interventions.

- NeuroCovid Stage II: SARS-Cov2 activates a robust immune response with high levels of cytokines, which in term increase the levels of ferritin, C-reactive protein, and D-dimer. The resulting hypercoagulable state triggers the formation of blood clots and thus patients may experience strokes, due to either arterial occlusion or venous thrombosis. The heightened immune response also causes vasculitis in muscles or nerves, in addition to immune-mediated "molecular mimicry" which damages cranial nerves, peripheral nerves, and/or muscles. 


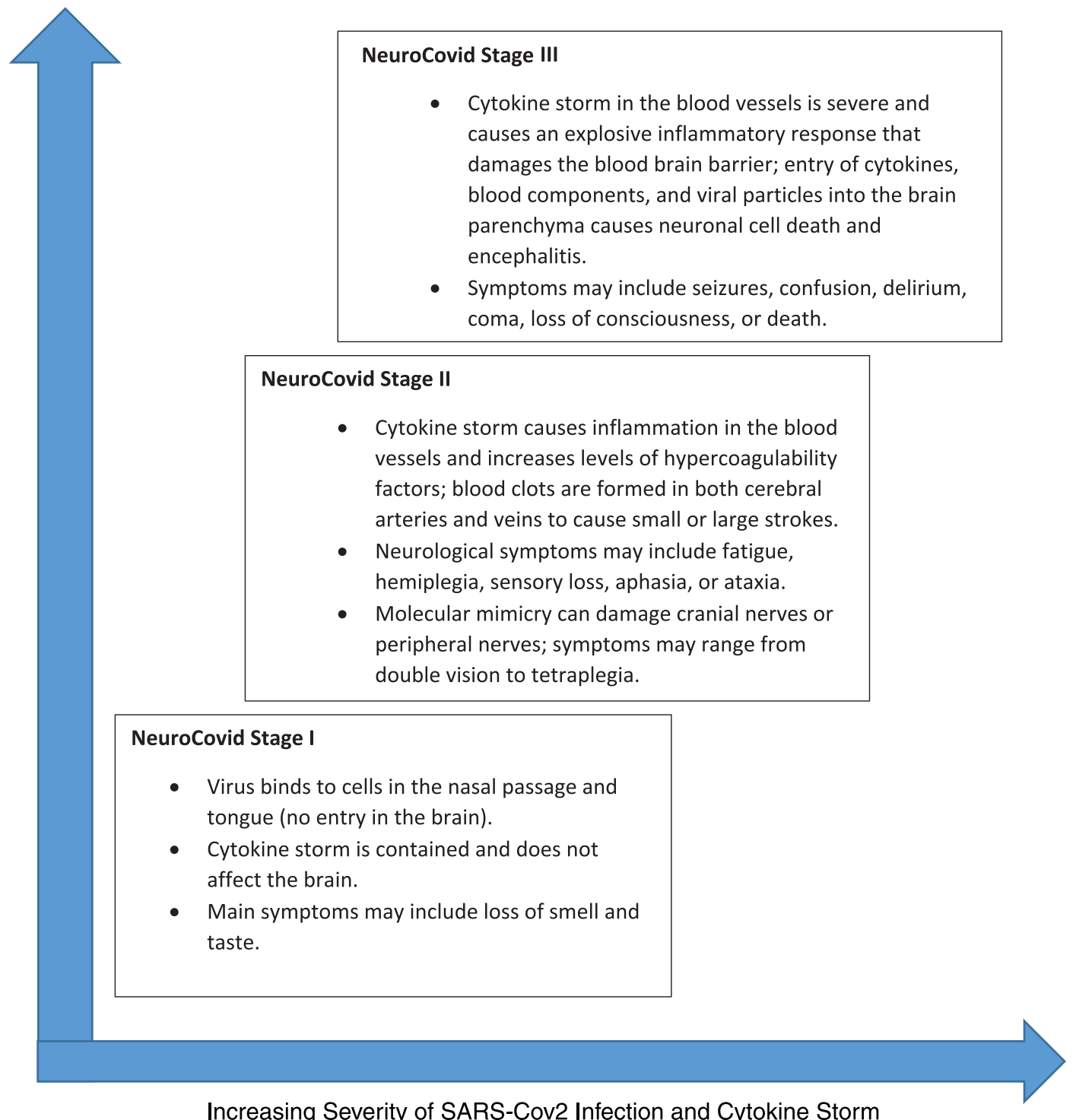

Fig. 4. NeuroCovid Stage I, II, and III. SARS-Cov2's neurological manifestation can be grouped into three stages. In NeuroCovid Stage I, the virus damage is limited to epithelial cells of nose and mouth. In NeuroCovid Stage II, patients may experience blood clots in their brain or have auto-antibodies that damage their peripheral nerves and muscles. In NeuroCovid Stage III, the cytokine storm damages the blood-brain barrier and patients may develop seizures, coma, or encephalopathy.

- NeuroCovid Stage III: SARS-Cov2's cytokine storm damages the blood brain barrier and results in infiltration of inflammatory factors and other blood contents (including viral particles) in the cerebral milieu. The resultant edema and brain injury lead to delirium, encephalopathy and/or seizures. High titers of virus load occupy a higher portion of ACE2 in the blood, and as such, levels of angiotensin II increase. The resultant heightened peripheral vascular resistance and hypertension increase the risk of intracranial hemorrhage.

\section{LONG-TERM COMPLICATION: NEUROCOGNITIVE AND PSYCHIATRIC CONDITIONS}

Neurons contain significant levels of ACE2 and thus SARS-Cov2 can penetrate them and disrupt their 
cellular mechanism for energy production (mitochondria) and protein folding [83]. SARS-Cov2, as well as other corona viruses, can remain inside some neurons without being acutely toxic [11]. The abnormal misfolding and aggregation of proteins in patients who survive and recover from their acute SARS-Cov2 infection can thus theoretically lead to brain degeneration decades later[83]. Since some of the effects of SARS-Cov 2 can manifest months or years after infection, it will be necessary to consistently follow-up with patients who have been affected by COVID19. Keeping accurate registries of COVID-19 patients with neurological deficits may enable us to establish plausible connections with aging-associated and neurodegenerative disorders such as Parkinson's disease in the future. This possibility has been raised as there has been a link between SARS-Cov1 and a higher risk of developing Parkinson's disease[84] and multiple sclerosis [85].

We are still in early stages of the current pandemic and the focus of our medical interventions have been on the acute treatment of life-threatening consequences of COVID-19 such as pulmonary embolism, ARDS, myocardial infarctions, encephalitis, renal failure, paralysis, and coma. However, it is quite likely that the cytokine storm and the insults to the brain via small or large strokes, injury to BBB, and high levels of inflammation inside the brain would have long term neuropsychiatric consequences. Thus, the health care systems around the world may see in the coming years a wave of patients who present with depression, post-traumatic stress disorder, anxiety, insomnia, or psychosis as well as cognitive impairment or decline. As was found with SARS-Cov1 and MERS, not all patients with SARS-Cov2 infection who leave the hospital will return to $100 \%$ of their baseline emotional and neurocognitive function. A study of neuropsychiatric sequelae of SARS-Cov1 31-50 months after the acute infection found evidence for post-traumatic stress disorder (39\%), depression $(36.4 \%)$, obsessive convulsive disorder $(15.6 \%)$, and panic disorders (15.6\%) [10].

The cytokine storm in COVID-19 can cause a series of small punctate strokes without causing noticeable neurological deficits [28]. When these patients leave the hospital after an acute SARSCov2 infection, they may experience poor memory, attention, or slow processing speed. Thus, it would be helpful for these patients to see a neurologist or undergo neurocognitive testing 6-8 months after their hospital discharge if they feel they still have cognitive issues, slowness in processing information, or poor attention. Patients with low scores in certain cognitive domains can consider receiving brain rehabilitation in order to return to their baseline level of cognitive capacity. By doing so, they would reduce their risk for developing a worse case of age-related cognitive decline later in life [86, 87].

One of the most consistent findings in COVID-19 literature is that patients with vascular risk factors such as obesity, hypertension, and diabetes have a more dire outcome as compared to healthy and fit individuals who get infected with SARS-Cov2. As such, a strategy of regular exercise, eating a heart healthy diet, reducing stress, improving sleep, and following other recommendations for reducing risk of heart attacks and strokes now prove more critical than ever before [86, 87]. By becoming a host that is resilient to SARS-Cov2, COVID-19 patients can improve their odds of a faster and more favorable recovery.

\section{COVID-19 IN PATIENETS WITH ALZHEIMER'S DISEASE AND OTHER NEUROLOGICAL DISORDERS}

Patients with Alzheimer's disease may be at a higher risk of developing COVID-19 [88]. They may not be able to follow recommendations from public health authorities regarding prevention of SARSCov2 infection such as hand hygiene, covering mouth and nose when coughing, maintaining physical distance from others, or remaining at home. They may not understand, appreciate, or remember what they need to do. If they have depression, malaise, reduce mobility, and apathy, they may also be unwilling or unable to comply with any rules. Finally, some patients with severe Alzheimer's disease who have agitation, wandering, or psychosis may refuse to be isolated. Their behavior may also put them at risk for further dementia related decline-especially if they are kept in a hospital environment and away from their family members or familiar surroundings. Prolonged hospitalization would have dire consequences for these patients. As such, caring for patients with Alzheimer's disease, who are often older and have multiple risk factors for experiencing a poor outcome (or death) if they become infected with SARS-Cov2, poses a major public health challenge for caregivers, health care professionals, and nursing homes [88].

Patients with other neurological disorders are also at risk for multiple complications associated with COVID-19. Those with a previous history of cere- 
brovascular disease often have a poor outcome if they develop COVID-19 [89]. Patients with neuromuscular disorder such as myasthenia gravis may experience a relapse of their symptoms and there may be even an increase in incidence of this condition during the COVID-19 pandemic [79]. Patients with multiple sclerosis, amyotrophic lateral sclerosis, and respiratory dysfunction are likely to have difficulty surviving ICU hospitalization and those on immunosuppressive medications may decline faster $[79,90]$. Neurologists need to be particularly mindful of COVID-19 issues that can directly impact the care of their patients with these disorders.

\section{IMPLICATIONS FOR THE PRACTICE OF NEUROLOGY IN THE FUTURE}

Given that cytokine-induced hypercoagulability and formation of blood clots in the lungs, heart, kidney, and brain pose significant morbidity and mortality in COVID-19 patients, treatment with antiplatelet or anticoagulant medications such as aspirin or heparin needs to be studied. The prevention of vascular events can lead to lower rates of pulmonary embolism, heart attacks, kidney failure, and embolic strokes. Clinical trials to test this hypothesis need to begin promptly. There is also a need for clinical trials which document and record the acute onset of neurological symptoms, detailed neurological test results, progression, and long-term recovery of symptoms in patients with COVID-19.

Given that some patients with COVID-19 can present to hospitals or outpatient clinics with neurological symptoms as their only symptom of SARS-Cov2 infections, neurologists therefore need to be mindful of the risk of infection spreading by such patients to staff or other patients in the clinical area [2]. In the future, we may need a pre-visit screening with questionnaires that check for anosmia, ageusia, fever, cough, shortness of breath, or living with family members who have been infected with SARS-Cov2. We may also make it mandatory that we measure the temperature, blood pressure, heart rate, and oxygen saturation in all patients who walk into a neurology practice.

Finally, it remains important to understand that while patients with COVID-19 can present with a wide range of neurological symptoms ranging from anosmia, cranial nerve palsy, weakness, strokes, to seizures or encephalopathy, they may still have other etiologies for their acute or chronic neurolog- ical issues. A patient with new onset of unilateral weakness, seizure, or diplopia may still have a nonCOVID-19 etiology, even if they are found to have a recent SARS-Cov2 infection. We need to add COVID-19 to the list of differential diagnosis for our patients in a neurology unit and remain mindful that patients need to have a full standard work-up for their evaluation and treatment. Neurologists need to consider ordering blood tests for levels of cytokines, D-dimer, CRP, ferritin, and lymphocytes as well as SARS-Cov2 PCR and/or serology [7].

\section{CONCLUSIONS}

Patients with COVID-19 can present with a wide range of neurological manifestations that can be due to the injury to central and peripheral nervous system via a cytokine storm, blood clots, direct damage by SARS-Cov2, and/or molecular mimicry. This review, while presenting what is currently known about this virus and the related clinical neurology, represents only the base of what will eventually become a separate active field of research. Much work remains to determine a fuller understanding of the underlying neurobiology of COVID-19. These include better characterized COVID-19 cohorts with longitudinal follow ups. Standardized evaluations such as quantitative EEG, fluid biomarkers, cognitive evaluations, and multi-modal neuroimaging can also lend insight to possible long-term neurological sequalae in COVID-19 such as depression, memory loss, mild cognitive impairment, or Alzheimer's disease.

\section{ACKNOWLEDGMENTS}

Dr. Mian receives education funding from the Washington University Carol B. and Jerome T. Loeb Teaching Fellows program. Dr. Meysami is supported by McLoughlin Cognitive Health Gift Fund and the Pituitary Injury Foundation. Dr. Raji is supported in his research by grants from the WUSTL NIH KL2 Grant (KL2 TR000450 - ICTS Multidisciplinary Clinical Research Career Development Program), the Radiological Society of North America Research Scholar Grant and the Foundation of the American Society of Neuroradiology Boerger Research Fund for Alzheimer's Disease and Neurocognitive Disorders. We thank Ms. Melissa Hussey for her assistance in preparation of this manuscript.

Authors' disclosures available online (https:// www.j-alz.com/manuscript-disclosures/20-0581r1). 


\section{REFERENCES}

[1] Naming the coronavirus disease (COVID-19) and the virus that causes it. https://www.who.int/emergencies/diseases/ novel-coronavirus-2019/technical-guidance/naming-the-co ronavirus-disease-(covid-2019)-and-the-virus-that-causesit. Accessed May 1, 2020

[2] Pleasure SJ, Green AJ, Josephson SA (2020) The spectrum of neurologic disease in the severe acute respiratory syndrome coronavirus 2 pandemic infection: neurologists move to the frontlines. JAMA Neurol, doi:10.1001/jamaneurol.2020.1065

[3] Liu K, Pan M, Xiao Z, Xu X (2020) Neurological manifestations of the coronavirus (SARS-cov-2) pandemic 2019-2020. J Neurol Neurosurg Psychiatry 91, 669-670.

[4] Ogier M, Andéol G, Sagui E, Bo GD (2020) How to detect and track chronic neurologic sequelae of COVID19 ? Use of auditory brainstem responses and neuroimaging for long-term patient follow-up. Brain Behav Immun Health 5, 100081 .

[5] Bridwell R, Long B, Gottlieb M (2020) Neurologic complications of COVID-19. Am J Emerg Med, doi: 10.1016/j.ajem.2020.05.024

[6] Mao L, Jin H, Wang M, Hu Y, Chen S, He Q, Chang J, Hong C, Zhou Y, Wang D, Miao X, Li Y, Hu B (2020) Neurologic manifestations of hospitalized patients with coronavirus disease 2019 in Wuhan, China. JAMA Neurol, doi:10.1001/jamaneurol.2020.1127

[7] Li Z, Liu T, Yang N, Han D, Mi X, Li Y, Liu K, Vuylsteke A, Xiang H, Guo X (2020) Neurological manifestations of patients with COVID-19: Potential routes of SARS-cov-2 neuroinvasion from the periphery to the brain. Front Med, doi: 10.1007/s11684-020-0786-5

[8] Chen T, Wu D, Chen H, Yan W, Yang D, Chen G, Ma K, Xu D, Yu H, Wang H, Wang T, Guo W, Chen J, Ding C, Zhang X, Huang J, Han M, Li S, Luo X, Zhao J, Ning Q (2020) Clinical characteristics of 113 deceased patients with coronavirus disease 2019: retrospective study. BMJ 368, m1091

[9] Phua J, Weng L, Ling L, Egi M, Lim C-M, Divatia JV, Shrestha BR, Arabi YM, Ng J, Gomersall CD, Nishimura M, Koh Y, Du B (2020) Intensive care management of coronavirus disease 2019 (COVID-19): challenges and recommendations. Lancet Respir Med 8, 506-517.

[10] Troyer EA, Kohn JN, Hong S (2020) Are we facing a crashing wave of neuropsychiatric sequelae of COVID-19? Neuropsychiatric symptoms and potential immunologic mechanisms. Brain Behav Immun, doi: 10.1016/j.bbi.2020.04.027

[11] Nath A (2020) Neurologic complications of coronavirus infections. Neurology 94, 809-810.

[12] Wu Y, Xu X, Chen Z, Duan J, Hashimoto K, Yang L, Liu C, Yang C (2020) Nervous system involvement after infection with COVID-19 and other coronaviruses. Brain Behav Immun, doi: 10.1016/j.bbi.2020.03.031

[13] de Wit E, van Doremalen N, Falzarano D, Munster V SARS and MERS: recent insights into emerging coronaviruses. Nat Rev Microbiol 14, 523-534.

[14] Algahtani H, Subahi A, Shirah B (2016) Neurological complications of Middle East Respiratory Syndrome Coronavirus: a report of two cases and review of the literature. Case Rep Neurol Med 2016, 3502683.

[15] Lu R, Zhao X, Li J, Niu P, Yang B, Wu H, Wang W, Song H, Huang B, Zhu N, Bi Y, Ma X, Zhan F, Wang L, Hu T, Zhou H, Hu Z, Zhou W, Zhao L, Chen J, Meng Y, Wang J, Lin Y, Yuan J, Xie Z, Ma J, Liu WJ, Wang D, Xu W, Holmes EC, Gao GF, Wu G, Chen W, Shi W, Tan W (2020) Genomic characterisation and epidemiology of 2019 novel coronavirus: implications for virus origins and receptor binding. Lancet 395, 565-574.

[16] Galougahi MK, Ghorbani J, Bakhshayeshkaram M, Naeini AS, Haseli S (2020) Olfactory bulb magnetic resonance imaging in SARS-cov-2-induced anosmia: the first report. Acad Radiol 27, 892-893.

[17] Lechien JR, Chiesa-Estomba CM, De Siati DR, Horoi M, Le Bon SD, Rodriguez A, Dequanter D, Blecic S, El Afia F, Distinguin L, Chekkoury-Idrissi Y, Hans S, Delgado IL, Calvo-Henriquez C, Lavigne P, Falanga C, Barillari MR, Cammaroto G, Khalife M, Leich P, Souchay C, Rossi C, Journe F, Hsieh J, Edjlali M, Carlier R, Ris L, Lovato A, De Filippis C, Coppee F, Fakhry N, Ayad T, Saussez S (2020) Olfactory and gustatory dysfunctions as a clinical presentation of mild-to-moderate forms of the coronavirus disease (COVID-19): a multicenter European study. Eur Arch Otorhinolaryngol, doi: 10.1007/s00405-020-05965-1

[18] Spinato G, Fabbris C, Polesel J, Cazzador D, Borsetto D, Hopkins C, Boscolo-Rizzo P (2020) Alterations in smell or taste in mildly symptomatic outpatients with SARS-cov-2 infection. JAMA 323, 2089-2090.

[19] Giacomelli A, Pezzati L, Conti F, Bernacchia D, Siano M, Oreni L, Rusconi S, Gervasoni C, Ridolfo AL, Rizzardini G, Antinori S, Galli M (2020) Self-reported olfactory and taste disorders in patients with severe acute respiratory coronavirus 2 infection: a cross-sectional study. Clin Infect Dis, doi: 10.1093/cid/ciaa330

[20] Lovato A, de Filippis C, Marioni G (2020) Upper airway symptoms in coronavirus disease 2019 (COVID-19). Am J Otolaryngol, doi: 10.1016/j.amjoto.2020.102474

[21] Li Y, Wang M, Zhou Y, Chang J, Xian Y, Mao L, Hong $\mathrm{C}$, Chen S, Wang Y, Wang H, Li M, Jin H, Hu B (2020) Acute Cerebrovascular Disease Following COVID19: A Single Center, Retrospective, Observational Study, Social Science Research Network, Rochester, NY. Doi: 10.2139/ssrn.3550025

[22] Oxley TJ, Mocco J, Majidi S, Kellner CP, Shoirah H, Singh IP, De Leacy RA, Shigematsu T, Ladner TR, Yaeger KA, Skliut M, Weinberger J, Dangayach NS, Bederson JB, Tuhrim S, Fifi JT (2020) Large-vessel stroke as a presenting feature of Covid-19 in the young. $N$ Engl J Med 382, e60.

[23] Filatov A, Sharma P, Hindi F, Espinosa PS (2020) Neurological complications of coronavirus disease (COVID-19): encephalopathy. Cureus 12, e7352.

[24] Moriguchi T, Harii N, Goto J, Harada D, Sugawara H, Takamino J, Ueno M, Sakata H, Kondo K, Myose N, Nakao A, Takeda M, Haro H, Inoue O, Suzuki-Inoue K, Kubokawa K, Ogihara S, Sasaki T, Kinouchi H, Kojin H, Ito M, Onishi H, Shimizu T, Sasaki Y, Enomoto N, Ishihara H, Furuya S, Yamamoto T, Shimada S (2020) A first case of meningitis/encephalitis associated with SARS-Coronavirus-2. Int J Infect Dis 94, 55-58.

[25] Poyiadji N, Shahin G, Noujaim D, Stone M, Patel S, Griffith B (2020) COVID-19-associated acute hemorrhagic necrotizing encephalopathy: CT and MRI features. Radiology, doi: 10.1148/radiol.2020201187

[26] Duong L, Xu P, Liu A (2020) Meningoencephalitis without respiratory failure in a young female patient with COVID19 infection in Downtown Los Angeles, early April 2020. Brain Behav Immun, doi: 10.1016/j.bbi.2020.04.024

[27] Yin R, Feng W, Wang T, Chen G, Wu T, Chen D, Lv T, Xiang D (2020) Concomitant neurological symptoms observed in a patient diagnosed with coronavirus disease 2019. J Med Virol, doi: 10.1002/jmv.25888. 
[28] Helms J, Kremer S, Merdji H, Clere-Jehl R, Schenck M, Kummerlen C, Collange O, Boulay C, Fafi-Kremer S, Ohana M, Anheim M, Meziani F (2020) Neurologic features in severe SARS-cov-2 infection. $N$ Engl J Med 382, 2268-2270.

[29] Gutiérrez-Ortiz C, Méndez A, Rodrigo-Rey S, San PedroMurillo E, Bermejo-Guerrero L, Gordo-Mañas R, de Aragón-Gómez F, Benito-León J (2020) Miller Fisher Syndrome and polyneuritis cranialis in COVID-19. Neurology, doi: 10.1212/WNL.0000000000009619

[30] Toscano G, Palmerini F, Ravaglia S, Ruiz L, Invernizzi P, Cuzzoni MG, Franciotta D, Baldanti F, Daturi R, Postorino P, Cavallini A, Micieli G (2020) Guillain-Barré Syndrome associated with SARS-cov-2. N Engl J Med, doi: 10.1056/nejmc2009191.

[31] Bhatraju PK, Ghassemieh BJ, Nichols M, Kim R, Jerome KR, Nalla AK, Greninger AL, Pipavath S, Wurfel MM, Evans L, Kritek PA, West TE, Luks A, Gerbino A, Dale CR, Goldman JD, O'Mahony S, Mikacenic C (2020) Covid-19 in critically ill patients in the seattle region - case series. N Engl J Med 382, 2012-2022.

[32] Verdecchia P, Cavallini C, Spanevello A, Angeli F (2020) The pivotal link between ACE2 deficiency and SARS-cov-2 infection. Eur J Intern Med 76, 14-20.

[33] Kai H, Kai M (2020) Interactions of coronaviruses with ACE2, angiotensin II, and RAS inhibitors-lessons from available evidence and insights into COVID-19. Hypertens Res, doi: 10.1038/s41440-020-0455-8.

[34] Vaduganathan M, Vardeny O, Michel T, mcmurray JJV, Pfeffer MA, Solomon SD (2020) Renin-angiotensinaldosterone system inhibitors in patients with Covid-19. $N$ Engl J Med 382, 1653-1659.

[35] Magrone T, Magrone M, Jirillo E (2020) Focus on receptors for coronaviruses with special reference to angiotensinconverting enzyme 2 as a potential drug target - a perspective. Endocr Metab Immune Disord Drug Targets, doi: 10.2174/1871530320666200427112902.

[36] Li H, Liu S-M, Yu X-H, Tang S-L, Tang C-K (2020) Coronavirus disease 2019 (COVID-19): current status and future perspectives. Int J Antimicrob Agents 55, 105951.

[37] Li M-Y, Li L, Zhang Y, Wang X-S (2020) Expression of the SARS-cov-2 cell receptor gene ACE2 in a wide variety of human tissues. Infect Dis Poverty 9, 45.

[38] Mehta P, mcauley DF, Brown M, Sanchez E, Tattersall RS, Manson JJ (2020) COVID-19: consider cytokine storm syndromes and immunosuppression. Lancet 395, 10331034.

[39] Xiong M, Liang X, Wei Y (2020) Changes in blood coagulation in patients with severe coronavirus disease 2019 (COVID-19): a meta-analysis. Br J Haematol, doi.org/10.1111/bjh.16725

[40] Spiezia L, Boscolo A, Poletto F, Cerruti L, Tiberio I, Campello E, Navalesi P, Simioni P (2020) COVID-19related severe hypercoagulability in patients admitted to intensive care unit for acute respiratory failure. Thromb Haemost 120, 998-1000.

[41] Steenblock C, Todorov V, Kanczkowski W, Eisenhofer G, Schedl A, Wong M-L, Licinio J, Bauer M, Young AH, Gainetdinov RR, Bornstein SR (2020) Severe acute respiratory syndrome coronavirus 2 (SARS-cov-2) and the neuroendocrine stress axis. Mol Psychiatry, doi: 10.1038/s41380-020-0758-9

[42] Heffner KL (2011) Neuroendocrine effects of stress on immunity in the elderly: implications for inflammatory disease. Immunol Allergy Clin North Am 31, 95-108.
[43] Rogers JP, Chesney E, Oliver D, Pollak TA, McGuire P, Fusar-Poli P, Zandi MS, Lewis G, David AS (2020) Psychiatric and neuropsychiatric presentations associated with severe coronavirus infections: a systematic review and meta-analysis with comparison to the COVID-19 pandemic. Lancet Psychiatry, doi: 10.1016/S2215-0366(20)30203-0.

[44] Xydakis MS, Dehgani-Mobaraki P, Holbrook EH, Geisthoff UW, Bauer C, Hautefort C, Herman P, Manley GT, Lyon DM, Hopkins C (2020) Smell and taste dysfunction in patients with COVID-19. Lancet Infect Dis, doi: 10.1016/S1473-3099(20)30293-0.

[45] Vaira LA, Salzano G, Deiana G, Riu GD (2020) Anosmia and ageusia: common findings in COVID-19 patients. Laryngoscope, doi.org/10.1002/lary.28692.

[46] Small DM, Prescott J (2005) Odor/taste integration and the perception of flavor. Exp Brain Res 166, 345-357.

[47] Vaira LA, Salzano G, Fois AG, Piombino P, Riu GD (2020) Potential pathogenesis of ageusia and anosmia in COVID-19 patients. Int Forum Allergy Rhinol, doi.org/10.1002/alr.22593.

[48] Yan CH, Faraji F, Prajapati DP, Boone CE, DeConde AS (2020) Association of chemosensory dysfunction and Covid-19 in patients presenting with influenza-like symptoms. Int Forum Allergy Rhinol, doi: 10.1002/alr.22579.

[49] Sungnak W, Huang N, Bécavin C, Berg M, Queen R, Litvinukova M, Talavera-López C, Maatz H, Reichart D, Sampaziotis F, Worlock KB, Yoshida M, Barnes JL (2020) SARS-cov-2 entry factors are highly expressed in nasal epithelial cells together with innate immune genes. Nat Med 26, 681-687.

[50] Xu H, Zhong L, Deng J, Peng J, Dan H, Zeng X, Li T, Chen Q (2020) High expression of ACE2 receptor of 2019ncov on the epithelial cells of oral mucosa. Int J Oral Sci $12,8$.

[51] Conde Cardona G, Quintana Pájaro LD, Quintero Marzola ID, Ramos Villegas Y, Moscote Salazar LR (2020) Neurotropism of SARS-cov 2: mechanisms and manifestations. J Neurol Sci 412, 116824.

[52] Baig AM, Khaleeq A, Ali U, Syeda H (2020) Evidence of the COVID-19 virus targeting the CNS: tissue distribution, host-virus interaction, and proposed neurotropic mechanisms. ACS Chem Neurosci 11, 995-998.

[53] Butowt R, Bilinska K (2020) SARS-cov-2: olfaction, brain infection, and the urgent need for clinical samples allowing earlier virus detection. ACS Chem Neurosci 11, 1200-1203.

[54] Vaira LA, Hopkins C, Salzano G, Petrocelli M, Melis A, Cucurullo M, Ferrari M, Gagliardini L, Pipolo C, Deiana G, Fiore V, De Vito A, Turra N, Canu S, Maglio A, Serra A, Bussu F, Madeddu G, Babudieri S, Giuseppe Fois A, Pirina P, Salzano FA, De Riu P, Biglioli F, De Riu G (2020) Olfactory and gustatory function impairment in COVID19 patients: Italian objective multicenter-study. Head Neck, doi: 10.1002/hed.26269.

[55] Gu J, Gong E, Zhang B, Zheng J, Gao Z, Zhong Y, Zou W, Zhan J, Wang S, Xie Z, Zhuang H, Wu B, Zhong H, Shao H, Fang W, Gao D, Pei F, Li X, He Z, Xu D, Shi X, Anderson VM, Leong AS-Y (2005) Multiple organ infection and the pathogenesis of SARS. J Exp Med 202, 415-424.

[56] Cao Y, Li L, Feng Z, Wan S, Huang P, Sun X, Wen F, Huang X, Ning G, Wang W (2020) Comparative genetic analysis of the novel coronavirus (2019-ncov/SARS-cov-2) receptor ACE2 in different populations. Cell Discov 6, 11.

[57] Li W, Zhang C, Sui J, Kuhn JH, Moore MJ, Luo S, Wong S-K, Huang I-C, Xu K, Vasilieva N, Murakami A, He Y, Marasco WA, Guan Y, Choe H, Farzan M (2005) Receptor 
and viral determinants of SARS-coronavirus adaptation to human ACE2. EMBO J 24, 1634-1643.

[58] Fang L, Karakiulakis G, Roth M (2020) Are patients with hypertension and diabetes mellitus at increased risk for COVID-19 infection? Lancet Respir Med 8, e21.

[59] Zhou B, She J, Wang Y, Ma X (2020) A case of coronavirus disease 2019 with concomitant acute cerebral infarction and deep vein thrombosis. Front Neurol 11, 296.

[60] Carter SJ, Baranauskas MN, Fly AD (2020) Considerations for obesity, vitamin D, and physical activity amidst the COVID-19 pandemic. Obesity (Silver Spring), doi: 10.1002/oby. 22838

[61] Sattar N, Mcinnes IB, Mcmurray JJV (2020) Obesity a risk factor for severe COVID-19 infection: multiple potential mechanisms. Circulation, doi: 10.1161/CIRCULATIONAHA.120.047659

[62] Umapathi T, Kor AC, Venketasubramanian N, Lim CCT, Pang BC, Yeo TT, Lee CC, Lim PL, Ponnudurai K, Chuah KL, Tan PH, Tai DYH, Ang SPB (2004) Large artery ischaemic stroke in severe acute respiratory syndrome (SARS). J Neurol 251, 1227-1231.

[63] Avula A, Nalleballe K, Narula N, Sapozhnikov S, Dandu V, Toom S, Glaser A, Elsayegh D (2020) COVID19 presenting as stroke. Brain Behav Immun, doi: 10.1016/j.bbi.2020.04.077

[64] Basu-Ray I, Soos MP (2020) Cardiac manifestations of coronavirus (COVID-19). In statpearls. Statpearls Publishing, Treasure Island, FL.

[65] Jose RJ, Manuel A (2020) COVID-19 cytokine storm: The interplay between inflammation and coagulation. Lancet Respir Med, doi: 10.1016/S2213-2600(20)30216-2

[66] Wang H-Y, Li X-L, Yan Z-R, Sun X-P, Han J, Zhang BW (2020) Potential neurological symptoms of COVID-19. Ther Adv Neurol Disord 13, 175628642091783.

[67] Delanghe JR, Speeckaert MM, De Buyzere ML (2020) The host's angiotensin-converting enzyme polymorphism may explain epidemiological findings in COVID-19 infections. Clin Chim Acta 505, 192-193.

[68] Kotfis K, Williams Roberson S, Wilson JE, Dabrowski W, Pun BT, Ely EW (2020) COVID-19: ICU delirium management during SARS-cov-2 pandemic. Crit Care 24, 176.

[69] Zambrelli E, Canevini M, Gambini O, D’Agostino A (2020) Delirium and sleep disturbances in COVID-19: a possible role for melatonin in hospitalized patients? Sleep Med 70, 111.

[70] van Vliet EA, da Costa Araujo S, Redeker S, van Schaik R, Aronica E, Gorter JA (2007) Blood-brain barrier leakage may lead to progression of temporal lobe epilepsy. Brain 130, 521-534.

[71] Sweeney MD, Sagare AP, Zlokovic BV (2018) Blood-brain barrier breakdown in Alzheimer's disease and other neurodegenerative disorders. Nat Rev Neurol 14, 133-150.

[72] Xu J, Zhong S, Liu J, Li L, Li Y, Wu X, Li Z, Deng P, Zhang J, Zhong N, Ding Y, Jiang Y (2005) Detection of severe acute respiratory syndrome coronavirus in the brain: potential role of the chemokine Mig in pathogenesis. Clin Infect Dis 41, 1089-1096.

[73] Li Y-C, Bai W-Z, Hashikawa T (2020) Response to Commentary on "The neuroinvasive potential of SARS-cov-2 may play a role in the respiratory failure of COVID-19 patients." J Med Virol, doi: 10.1002/jmv.25824.
[74] Ye M, Ren Y, Lv T (2020) Encephalitis as a clinical manifestation of COVID-19. Brain Behav Immun, doi: 10.1016/j.bbi.2020.04.017.

[75] Al Saiegh F, Ghosh R, Leibold A, Avery MB, Schmidt RF, Theofanis T, Mouchtouris N, Philipp L, Peiper SC, Wang ZX, Rincon F, Tjoumakaris SI, Jabbour P, Rosenwasser RH, Gooch MR (2020) Status of SARS-cov-2 in cerebrospinal fluid of patients with COVID-19 and stroke. J Neurol Neurosurg Psychiatry, doi: 10.1136/jnnp-2020-323522.

[76] Zhao H, Shen D, Zhou H, Liu J, Chen S (2020) GuillainBarré syndrome associated with SARS-cov-2 infection: causality or coincidence? Lancet Neurol 19, 383-384.

[77] Sedaghat Z, Karimi N (2020) Guillain Barre syndrome associated with COVID-19 infection: A case report. J Clin Neurosci 76, 233-235.

[78] Ang CW, Jacobs BC, Laman JD (2004) The GuillainBarré syndrome: a true case of molecular mimicry. Trends Immunol 25, 61-66.

[79] Guidon AC, Amato AA (2020) COVID-19 and neuromuscular disorders. Neurology 94, 959-969.

[80] Li Z, Huang Y, Guo X (2020) The brain, another potential target organ, needs early protection from SARS-cov-2 neuroinvasion. Sci China Life Sci 63, 771-773.

[81] Li Y, Bai W, Hashikawa T (2020) The neuroinvasive potential of SARS-cov2 may play a role in the respiratory failure of COVID-19 patients. J Med Virol 92, 552-555.

[82] Hamming I, Timens W, Bulthuis MLC, Lely AT, Navis GJ, Goor $\mathrm{H}$ van (2004) Tissue distribution of ACE2 protein, the functional receptor for SARS coronavirus. A first step in understanding SARS pathogenesis. J Pathol 203, 631-637.

[83] Lippi A, Domingues R, Setz C, Outeiro TF, Krisko A (2020) SARS-cov-2: at the crossroad between aging and neurodegeneration. Mov Disord 35, 716-720.

[84] Fazzini E, Fleming J, Fahn S (1992) Cerebrospinal fluid antibodies to coronavirus in patients with Parkinson's disease. Mov Disord 7, 153-158.

[85] Murray RS, Cai GY, Hoel K, Johnson S, Cabirac GF (1993) Coronaviruses and multiple sclerosis. Adv Exp Med Biol 342, 353-357.

[86] Fotuhi M, Hachinski V, Whitehouse PJ (2009) Changing perspectives regarding late-life dementia. Nat Rev Neurol $\mathbf{5}, 649-658$.

[87] Fotuhi M, Do D, Jack C (2012) Modifiable factors that alter the size of the hippocampus with ageing. Nat Rev Neurol 8 , 189-202.

[88] Brown EE, Kumar S, Rajji TK, Pollock BG, Mulsant BH (2020) Anticipating and mitigating the impact of the COVID-19 pandemic on Alzheimer's disease and related dementias. Am J Geriatr Psychiatry, doi: 10.1016/j.jagp.2020.04.010.

[89] Siniscalchi A, Gallelli L (2020) Could COVID-19 represents a negative prognostic factor in patients with stroke? Infect Control Hosp Epidemiol, doi: 10.1017/ice.2020.146.

[90] Manji H, Carr AS, Brownlee WJ, Lunn MP (2020) Neurology in the time of COVID-19. I Neurol Neurosurg Psychiatry 91, 568-570.

[91] Lu L, Xiong W, Liu D, Liu J, Yang D, Li N, Mu J, Guo J, Li W, Wang G, Gao H, Zhang Y, Lin M, Chen L, Shen S, Zhang H, Sander JW, Luo J, Chen S, Zhou D (2020) New-onset acute symptomatic seizure and risk factors in Corona Virus Disease 2019: a retrospective multicenter study. Epilepsia, doi: 10.1111/epi.16524. 